\title{
Challenges and Prospects of Green Marketing - A Study
}

\author{
MBS Sravanthi ${ }^{1}$ and Amruth Prasad Reddy ${ }^{2}$ \\ ${ }^{1}$ Research Scholar and ${ }^{2}$ Assistant Professor, Department of Business Administration, \\ Yogi Vemana University, Kadapa, Andhra Pradesh, India.
}

CITATION: Sravanthi, MBS and Reddy, Amruth Prasad (2020), "Challenges and Prospects of Green Marketing - A Study", MERC Global's International Journal of Management, Vol. 8, Issue 1, pp. 1924.

ARTICLE HISTORY: Submitted: July 03, 2019, Revision received: September 05, 2019, Accepted: September 15, 2019

ARTICLE TYPE: Research paper

\begin{abstract}
Green marketing has been emerged due to increased acid rains, depletion of the ozone layer, degradation of the land, deforestation, increasing pollution, and greenhouse gas effect, etc. Green marketing is a 'Go Green' concept has been introduced into the production process of a product which is environmentally safe and makes a profit for the organisations by satisfying consumers. Green marketing is a new concept and hence draw a new idea is not easily accepted. The practice green marketing a huge investment in the area of research and development is needed. Three factors that may influence the green marketing were examined in this study: challenges and prospects of green marketing benefits with green marketing, the role of government initiatives to promote ecofriendly products. Data were collected from the Rayalaseema Region of Andhra Pradesh, and all factors were found to have positive effects on purchasing green products. The results also indicated that the consumers buying green products due to environmental problems were the main contributor to buying green products.
\end{abstract}

KEYWORDS: Eco-friendly, Environment, Waste management, Energy conservation, Campaign.

\section{REFERENCES}

1. Dima, I. C. and Vladutescu, S. (2012), "The Environment of organisational Entities and its Influence on Decisional Communication”, International Journal of Management Science and Business Research, Vol. 01, Issue 09, pp. 1-11.

2. Garg, Singal R. and Singh, D. S. (2012), "Green Marketing: challenges and opportunities", International Journal of Innovations in Engineering and Technology, Vol. 02, Issue 01, pp. 470-474.

3. Jain, Sanjay K. and Kaur, Gurmeet (2004), "Green Marketing: An attitudinal and behavioural analysis of Indian consumers", Global Business Review, Vol. 05, Issue 02, pp. 187-205.

4. McCarty, J. A. and Shrum, L. (1994), "The recycling of solid wastes: personal values, value orientations and attitudes about recycling as antecedents of recycling behaviour", Journal of Business Research, Vol. 30, Issue 02, pp. 53-62.

5. Mishra, Pavan and Sharma, Payal (2010), "Green Marketing in India: Emerging opportunities and challenges", Journal of Engineering, Science and Management Education, Vol. 03, pp. 09-14.

6. Mohan, Raj G. and Karthikeyan, P. (2016), "Green Marketing- New Opportunities and Challenges", Asian Journal of Research in Social Sciences and Humanities, Vol. 06, Issue 07, pp. 1240-1242. 